\title{
GAZA IN MEDIA EDITORIAL FRAME (SUARA PEMBARUAN, MEDIA INDONESIA, AND REPUBLIKA)
}

\author{
Anita Sieria \\ Program Studi Ilmu Komunikasi, Universitas Kristen Petra Surabaya \\ Email: anita.sieria@gmail.com
}

\begin{abstract}
Gaza strip has became the home for the longest lasting conflict between Israel and Palestine, even when the researcher doing this research, the conflict still remain. This conflict has become an important issue for the international world and has attracted various media coverage from all over the world including Indonesia. Many news, opinions, and editorials are involved in expressing arguments of different interests. Moreover, Indonesia has the largest Moslem population in the world, and therefore the conflict is often brought into the religious realm. Medias with different ideologies produce their reports with different frames. It is no surprise that people may have different perception about a situation in the conflict. This phenomenon, is the reason behind the writers interest in finding out how the Gaza conflict is being framed in Indonesian media editorial. Framing Analysis Method is being used to find out the differences of framing between the following medias: Suara Pembaruan (SP), Media Indonesia (MI), and Republika. It is found that differences in ideology influenced the framing of media editorial. Suara Pembaruan builds a frame that shows that Palestine (Hamas) is an extreme cluster causing negative effects, while Israel and United Nations's resolution viewed from a positive point of view. MI sees this conflict as political conflict. Republika perceives this conflict as an impact of Israel violence as well the paralyzed condition of the United Nation.
\end{abstract}

Keywords: Media frame, editorial, ideology.

\section{PENDAHULUAN}

Pada tahun 1947, Perserikatan Bangsa-Bangsa memutuskan untuk membagi daerah mandat PBB Britania Raya, Palestina. Tetapi hal ini ditentang keras oleh negara-negara Timur Tengah lainnya dan juga banyak negeri-negeri Muslim. Kaum Yahudi mendapat 55\% dari seluruh wilayah tanah meskipun hanya merupakan 30\% dari seluruh penduduk di daerah ini. Sedangkan kota Yerusalem yang dianggap suci, tidak hanya oleh orang Yahudi tetapi juga orang Muslim dan Kristen, akan dijadikan kota internasional. Namun dari hasil observasi peneliti, ada beberapa konflik yang terus terjadi akibat peristiwa bertahun-tahun silam tersebut. Konflik yang masih berlangsung bahkan sampai saat ini adalah konflik di jalur Gaza. Tindakan saling serang antara Israel dan Palestina mewarnai Jalur ini bertahun-tahun sampai memakan korban yang sudah tak sedikit lagi jumlahnya.

Kendati peristiwa kasus (konflik) Gaza terjadi di lokasi yang jauh dari Indonesia, namun kasus ini mendapat perhatian media nasional dan internasional baik media cetak, elektronik dan media online. Media massa di Indonesia memberikan perhatian yang cukup besar terhadap peristiwa kasus ini dalam 
pemberitaannya dan menempatkannya sebagai berita yang penting. Muatan atau isi beritanya antara lain berisikan aktivitas konflik (saling serang,dsb), kekuatan persenjataan, kerusakan akibat konflik, dan korban jiwa serta penderitaan masyarakat, selain itu dibahas juga mengenai sikap pemerintah Amerika sebagai penentu kebijaksanaan di PBB juga bagaimana sikap yang ditunjukkan baik oleh pemerintah maupun sebagian besar masyarakat Indonesia dalam menanggapi kasus tersebut. Hampir setiap hari selama akhir bulan Desember 2008 hingga awal bulan Februari 2009, media massa memberitakan kasus yang terjadi di jalur Gaza ini. Surat kabar nasional seperti Kompas, Jawa Pos, Republika, dan Suara Pembaruan, beberapa kali menjadikan berita ini sebagai headlines dan dimuat dalam rubrik internasional hampir setiap hari.

Konflik di Timur Tengah tidak hanya kali ini terjadi (akhir tahun 2008-awal 2009), beberapa tahun silam telah berulang kali terjadi konflik di Timur Tengah. Dengan adanya berbagai konflik terdahulu yang telah diberitakan dalam mediamedia cetak di Indonesia, maka beberapa penelitian dengan menggunakan metode framing telah dilakukan dengan subyek penelitian konflik Timur Tengah. Penelitian yang telah dilakukan antara lain terhadap surat kabar Kompas, Jawa Pos, dan Republika.

Dalam menggunakan analisis framing, yang dilakukan pertama-tama adalah bagaimana media-media tersebut membingkai konflik Timur Tengah, hasil penelitiannya bukan berupa 'siapa mendukung siapa'. Eriyanto, dalam bukunya Analisis Framing menjabarkan sebuah hasil penelitian yang dilakukan pada tahun 1994-1997, dalam penelitian tersebut ditemukan bahwa Kompas dan Republika mengembangkan bingkai dan konstruksi yang berbeda soal Timur Tengah. Bingkai itulah yang digunakan oleh kedua media tersebut dalam menilai seluruh peristiwa yang ada di Timur Tengah. Dalam bingkai Republika, kemerdekaan Palestina adalah solusi terbaik untuk mengatasi segala konflik di Timur Tengah. "Rangkaian peristiwa di Timur Tengah dikonstruksi Republika sebagai bagian dari kebiadaban Israel. Dalam bingkai Republika, segala tindakan yang dilakukan oleh Palestina akan selalu dipahami benar, sebaliknya apa yang dilakukan Israel selalu dipahami dengan tindakan yang salah. Dalam konsepsi dan konstruksi Kompas, solusi terbaik dalam menyelesaikan persoalan di Timur Tengah adalah dengan jalan damai. Kekerasan bukan hanya tidak akan menyelesaikan masalah, melainkan justru akan berakibat pada peperangan yang tak kunjung henti" (Eriyanto, 2007, p.7-8). Dalam penelitian lain yang dilakukan terhadap Jawa Pos didapati bahwa selama dimuat pemberitaanpemberitaan mengenai perang antar Israel dan Palestina, "Jawa Pos memiliki kecenderungan untuk lebih membenarkan tindakan pihak Palestina dan mengecam tindakan yang dilakukan oleh Israel dengan alasan apapun" (Panjaitan, 2008, p. 109110). Perbedaan bingkai tersebut yang dikatakan Eriyanto (2007), meyebabkan perbedaan bagaimana peristiwa itu dipahami. Bingkai itulah yang secara "salah" dipahami sebagai mendukung Israel atau Palestina.

Bermacam bingkai media di atas setidaknya memberitahukan bahwa media memiliki bingkai masing-masing yang tersaji melalui tulisan-tulisannya. Hal penting yang tidak boleh terlupakan adalah bahwa media massa sebagai alat komunikasi dalam kehidupan masyarakat memiliki berbagai macam peran. "Media massa berperan mendistribusikan informasi mengenai berbagai fakta yang terjadi di masyarakat, juga berperan dalam memberi makna atas sebuah isu atau 
permasalahan, menyeleksi berbagai hal yang perlu atau yang tidak perlu menjadi perhatian khalayak, menunjukkan arah dan menjelaskan tentang bermacam hal, serta menciptakan opini publik" (Subiakto, 1997, p. 15).

Berbagai peran media massa dalam konteks kehidupan sosial tersebut erat berkaitan dengan keberadaan media massa sebagai bagian integral dari institusiinstitusi sosial. Justru dalam proses interaksi dengan institusi sosial lain, seperti pemerintahan, partai politik, lembaga agama, dan lain-lain, media massa menjadi semakin menempati peran penting yang signifikan mempengaruhi segala aspek kehidupan masyarakat seperti politik, ekonomi, sosial dan budaya (Littlejohn, 2005).

Bila berbicara mengenai berbagai kepentingan yang mempengaruhi dunia pers, tentu tidak bisa terlepas dari fakta adanya peristiwa-peristiwa tertentu yang lebih menarik perhatian pers, salah satu realitas atau peristiwa yang menarik perhatian pers untuk diangkat menjadi sebuah berita adalah realitas politik. "Selain menarik untuk diberitakan, realitas politik seringkali dimuati berbagai kepentingan pihakpihak yang terkait di dalamnya. Peristiwa politik yang selalu menarik menjadi komoditas informasi pers meliputi: peristiwa rutin, peristiwa insidental, skandal, dan peristiwa yang ditemukan secara kebetulan tanpa disengaja" (Nimmo, 1993, p. 11) Dengan demikian dapat disimpulkan bahwa hampir setiap realitas atau peristiwa politik selalu menarik bagi media massa atau institusi dan pelaku-pelaku pers.

Salah satu peristiwa politik yang sangat menarik untuk diberitakan adalah peristiwa perang, di dalamnya terdapat hal-hal yang menarik perhatian dan rasa ingin tahu khalayak, "tragedi kemanusiaan, korban jiwa, pengungsi, kekuatan persenjataan, pro dan kontra yang diakibatkan perang tersebut, serta mengundang simpati terhadap korban" (Masduki, 2001, p. 22). Gabriella Mischkowski menyatakan bahwa media massa dapat menjadi bagian dari pada perang itu sendiri. Ia menerangkan bahwa perang tidak hanya dikobarkan oleh para tentara dan unit-unit para militer atau tentara bayaran tetapi media juga ikut memainkan peranan penting dalam berkobarnya suatu perang. "Sebuah perang bagaimanapun membutuhkan pemberitaan media. Pihak-pihak yang bertikai membutuhkan publikasi media atas klaim-klaim mereka. khalayak juga sangat tergantung pada pemberitaan media untuk mengetahui perkembangan perang" (Panjaitan, 2008, p. 4).

Memahami adanya hubungan saling menguntungkan antara media dan pihakpihak tertentu yang berkonflik dapat diasumsikan, berita tentang perang yang terdapat dalam media massa, dalam hal ini kasus Gaza pada tahun 2008-2009, telah dibangun berdasarkan kepentingan media itu sendiri dan pihak-pihak yang mempengaruhinya dan yang saling terkait dengan peristiwa itu. Misalnya media di Indonesia tentunya akan mempertimbangkan kepentingan kelompok Islam di Indonesia yang mendukung perjuangan Palestina-Hamas dan pemerintah serta politisi yang memakai peristiwa konflik tersebut menjadi bagian dari strategi politik di dalam negeri Indonesia.

Dengan membandingkan beberapa pemberitaan di media, akan ditemukan kesimpulan yang setara, bahwa media apa pun tidak bisa lepas dari bias-bias, baik yang berkaitan dengan ideologi, politik, sosial, ekonomi, sosial, budaya, bahkan agama. Tidak ada satupun media yang memiliki sikap independensi dan obyektivitas yang absolut. Tanpa adanya kesadaran seperti ini, mungkin saja khalayak menjadi bingung, merasa terombang-ambing dengan penyajian berita oleh media. 
Dalam pandangan konstruktivisme, berita adalah hasil dari pemaknaan wartawan dan media terhadap realitas, yang kemudian diekspresikan kembali menjadi realitas yang seolah obyektif. Karena itu peristiwa yang sama dapat dimaknai berbeda oleh wartawan atau media yang berbeda. Perbedaan ini juga dipengaruhi beberapa hal antara lain: rutinitas media, struktur organisasi, kekuatan ekstramedia, ideologi (Shoemaker dan Reese, 1996). Perbedaan-perbedaan cara pandang dan cara menyajikan media ini yang disebut sebagai pembingkaian.

Masing-masing media memiliki pembingkaian yang berbeda-beda, dan pembingkaian yang ada tidak akan terlihat begitu saja tanpa benar-benar dilihat dengan perangkat analisis yang tepat. Analisis framing merupakan salah satu alternatif model analisis yang dapat mengungkapkan rahasia dibalik semua perbedaan (bahkan pertentangan) media dalam mengungkapkan fakta. Analisis framing digunakan untuk mengetahui bagaimana realitas dibingkai oleh media, dengan cara dan teknik apa peristiwa ditekankan dan ditonjolkan. Apakah dalam berita itu ada bagian yang dihilangkan, luput, atau bahkan disembunyikan dalam pemberitaan. Bagaimana media memahami dan memaknai realitas, dan dengan cara apa realitas itu ditandakan, hal inilah yang menjadi pusat perhatian dari analisis framing. Pada intinya, analisis framing tidak melihat pada berita negatif atau positif namun melihat kepada media mengembangkan bingkai yang ada.

Model atau konsepsi framing yang akan digunakan dalam penelitian ini adalah model framing Gamson dan Modigliani. Gamson menyatakan bahwa frame menunjuk pada skema pemahaman individu sehingga seseorang dapat menempatkan, mempersepsi, mengidentifikasi, dan memberi label peristiwa dalam pemahaman tertentu. Dalam suatu peristiwa, framing berperan dalam mengorganisasi pengalaman dan petunjuk tindakan, baik secara individu maupun kolektif. Dalam pemahaman ini, tentu saja frame berperan sebagai aspek yang menentukan dalam partisipasi gerakan sosial. Dalam formulasi yang dibuat oleh Gamson dan Modigliani, frame dipandang sebagai cara bercerita (story line) atau gugusan ide-ide yang tersusun sedemikian rupa dan menghadirkan konstruksi makna dari peristiwa yang berkaitan dengan suatu wacana. Gamson melihat wacana media terdiri atas sejumlah kemasan melalui mana konstruksi atas suatu peristiwa dibentuk. Kemasan tersebut merupakan skema atau struktur pemahaman yang dipakai oleh seseorang ketika mengkonstruksi pesan-pesan yang dia sampaikan, dan menafsirkan pesan yang dia terima (Eriyanto, 2007, p. 89).

Untuk mengetahui bagaimana bingkai sikap, opini atau kecenderungan media terhadap suatu peristiwa politik tertentu, dapat dilihat dengan jelas dalam sebuah tajuk rencana atau editorial. Editorial mencerminkan jati diri dan sikap yang diambil oleh sebuah media atau sebuah institusi pers. Dalam editorial dapat dilihat sikap media yang dikemukakan secara lebih eksplisit ketimbang dalam sebuah pemberitaan (Stovall, 2005).

Kebijakan editorial dan kepentingan pemodal berpengaruh pula pada kebijakan penulisan tajuk rencana atau halaman editorial. Seleksi dan penetapan topik harus sesuai dengan klasifikasi penerbitan. Sebagai mahkota media, tajuk dipilih dengan sangat selektif. Kriterianya antara lain: topik harusnlah Aktual atau kontroversial, isi tajuk mencerminkan kebijakan media dan sejalan dengan kualifikasi serta fokus sirkulasi. Tajuk biasanya berpijak pada kaidah jurnalistik dan tidak bertentangan dengan aspek yang berlaku dalam masyarakat, serta berorientasi pada nilai-nilai 
luhur peradaban. Judul tajuk rencana dipilih sebagai jati diri menggunakan bahasa provokatif untuk menarik pembaca. (Menulis Artikel dan Tajuk Rencana, par. 2)

Ideologi sebuah media terlihat nyata di dalam editorialnya. Kecenderungan dan orientasi media pada "ideologi" yang dianutnya antara lain tercermin lewat cara mereka menggambarkan realitas dalam setiap pemberitaannya dan menyatakan sikapya lewat tajuk rencana. Ideologi itulah yang membuat liputan media massa memihak satu pandangan, menempatkan pandangan seseorang atau kelompok lebih penting dari pandangan dan pendapat lainnya.

"Halaman editorial ialah artikel dalam surat kabar yang mengekspresikan opini redaktur, jajaran redaksi, dan mewakili pernyataan sikap surat kabar secara keseluruhan. Kolom ini tetap dipertahankan karena dianggap sebagai jantung dan roih media. Surat kabar biasanya memuat editorial yang senada dengan kecondongan media tersebut tanpa memberi ruang seimbang untuk keseimbangan (cover both side) sebuah isu dan diskusi. Editorial kadang berisi solusi alternatif kepada masalah atau isu yang sedang diangkat" (Fenny, 2009, p. 7-8).

Begitu pentingnya editorial dalam sebuah media cetak, membawa muatan jati diri dan jiwa Surat Kabar, maka peneliti tertarik untuk mengetahui bagaimana SP, MI, dan Republika membingkai kasus Gaza dalam editorialnya. Editorial yang akan digunakan sebagai perangkat penelitian adalah tajuk atau editorial dari Surat Kabar Suara Pembaruan (SP), Republika dan Media Indonesia (MI). Asumsi dasar studi ini adalah bahwa framing editorial mengenai suatu peristiwa, dalam hal ini peristiwa kasus Gaza, dapat menunjukkan bagaimana pers mengkonstruksikan dan memaknai kasus atau kejadian ini. Framing kasus Gaza dalam teks tajuk rencana menunjukkan posisi dan opini pers yang bersangkutan dalam penelitian ini SP, Republika dan MI. Beranjak dari asumsi dasar ini, dengan mengkaji framing editorial mengenai kasus Gaza diharapkan dapat diperoleh gambaran bagaimana posisi pers Indonesia mengenai kasus internasional ini.

"Konflik terpanjang dalam sejarah umat manusia, perseteruan antara Palestina melibatkan begitu banyak aspek di dalamnya, sekaligus latar belakang yang sangat rumit, menjadikan isu ini sebagai isu yang sangaat sensitif. Posisi Indonesia sebagai negara berpenduduk Muslim terbesar di dunia, konflik Palestina-Israel seringkali dibawa ke dalam ranah agama" (Gandhi, 2009, p.134). Di Indonesia berbagai demonstrasi bermunculan dari kalangan Muslim yang tidak terima jika saudara Muslimnya (Palestina) menjadi korban penindasan brutal Israel (News and Comment, Republika-Israel Awetkan Mayat Pejuang Hizbullah, par.3). Bahkan kedekatan Psikologis dalam hal agama ini dimanfaatkan oleh Partai tertentu demi memperoleh simpati dan dukungan dari masyarakat Muslim saat Pemilu. Begitu kentalnya persoalan agama ini dikaitkan pada isu Israel-Palestina sehingga beberapa Surat Kabar pun memunculkan konstruksi agama dalam editorialnya. Maka dari itu peneliti tertarik membandingkan beberapa Surat Kabar dengan ideologi berbeda, yaitu dua Surat kabar dengan ideologi agama, dan 1 koran dengan ideologi nasionalis untuk melihat bingkai ketiga Surat Kabar ini terhadap isu israel-Palestina, khususnya setelah Israel melanggar Resolusi DK-PBB 1860 yang ditetapkan awal tahun 2009. 


\section{PEMBAHASAN}

Setelah menganalisis dengan perangkat framing Gamson and Modigliani, peneliti merangkum dalam tabel di bawah ini:

Tabel 1. Matriks perbandingan bingkai SP, MI, Republika

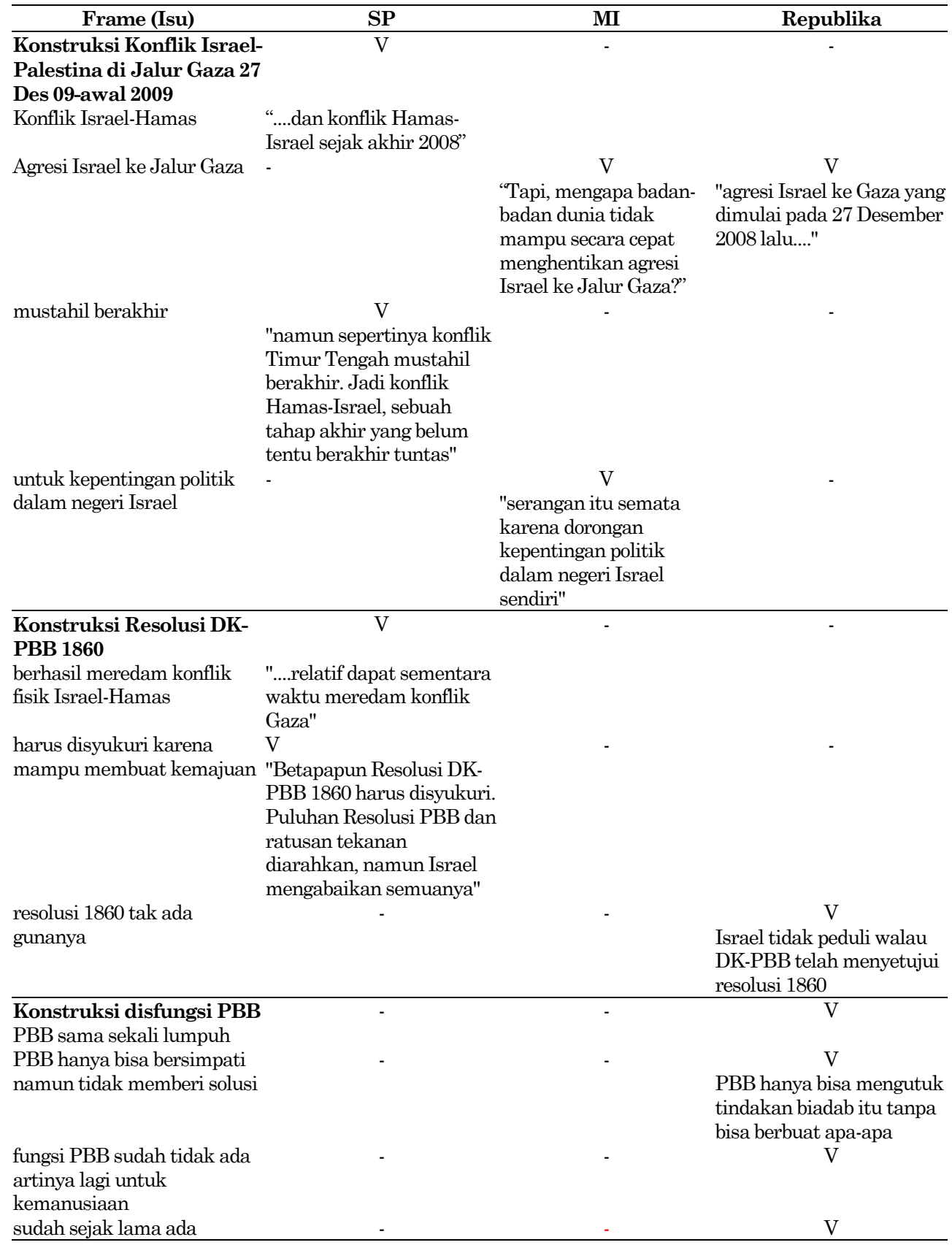




\begin{tabular}{llll}
\hline \multicolumn{1}{c}{ Frame (Isu) } & SP & MI & \multicolumn{1}{c}{ Republika } \\
\hline $\begin{array}{l}\text { penyimpangan dalam tubuh } \\
\text { PBB }\end{array}$ & & $\begin{array}{l}\text { 'Presiden Soekarno pernah } \\
\text { menyatakan sebaiknya } \\
\text { bubar saja PBB, kalau } \\
\text { para anggotanya tidak } \\
\text { memiliki hak yang sama } \\
\text { dalam forum } \\
\text { internasional" }\end{array}$ \\
$\begin{array}{l}\text { Konstruksi disfungsi } \\
\text { badan-badan dunia } \\
\text { badan-badan dunia } \\
\text { menerapkan standar ganda } \\
\text { standar ganda terutama } \\
\text { diterapkan oleh Negara barat } \\
\text { badan-badan dunia mandul } \\
\text { karena standar ganda } \\
\text { badan dunia tidak mampu } \\
\text { secara cepat mengatasi } \\
\text { konflik Israel-Palestina yang } \\
\text { telah berlangsung sangat } \\
\text { lama }\end{array}$ & - & $\mathrm{V}$ & \\
\hline
\end{tabular}

\section{Konstruksi SARA}

Tak peduli fasilitas umum maupun fasilitas ibadah betapa bengisnya pasukan zionis Israel

Dunia Arab sebagai representasi umat muslim
"Harapan dunia, Dunia

Arab, dan rakyat

Palestina, adalah kondisi

keamanan pulih kembali"
Konstruksi mengenai

\section{Israel}

menyerang untuk membalas

serangan roket Hamas

(serangan Israel bersifat responsif)

Israel menyerang Gaza untuk kepentingan politik dalam negerinya sendiri Israel terlebih dulu menutup pintu-pintu perbatasan (memulai serangan)

Israel memanfaatkan upaya diplomasi yang dilakukan Palestina (Fatah) untuk melancarkan tipu daya Israel menyerang tanpa pandang bulu

V

V

\section{$\mathrm{V}$}

(1)




\section{Frame (Isu) \\ Serangan roket Hamas yang} menyebabkan Israel membalas dengan serangan Hamas adalah kelompok yang ekstrem

Ekstremisme Hamas dengan V cara militernya tidak menyelesaikan masalah Serangan Hamas bersifat responsif (membalas Israel, untuk membela diri)

Hamas muncul sebagai reaksi atas kegagalan upaya diplomasi (Hamas hadir dengan solusi yang lebih baik)

Warga Palestina lebih menyukai pendekatan militeris Hamas

Sekutu Israel tidak menyukai keberadaan

Hamas yang disukai rakyat Palestina

Hamas merasa PBB tak dapat menjawab kebutuhan rakyat Palestina, Hamas merasa tak terkait lagi dengan resolusi PBB

\section{Konstruksi Penyelesaian} konflik Israel-Hamas di

\section{Jalur Gaza}

Cara militer justru memperburuk keadaan Seharusnya sikap moderat lebih menguntungkan bagi Palestina

Persatuan dan rekonsiliasi nasional Palestina harus terwujudkan

Upaya diplomasi merugikan pihak Palestina

Pemberian kemerdekaan kepada bangsa Palestina secepatnya adalah langkah yang utama

Setiap media massa (dalam penelitian ini adalah surat kabar), memiliki ideologi yang berbeda-beda, konstruksi yang disajikan dalam teksnya pun berbeda-beda
Hamas melancarkan serangan ke wilayah Yahudi karena israel terlebih dulu menutup pintu-pintu perbatasan yang menyulitkan warga Palestina di Jalur Gaza

$\mathrm{V}$<smiles>[V]</smiles>

$\mathrm{V}$ Republika

"Upaya diplomasi kerap "Akibat diabaikannya dimanfaatkan Israel Resolusi DK-PBB itu, untuk memperkuat diri Palestina merasa tak ada dan melancarkan tipu lagi gunanya resolusi DKdaya" PBB" 
sesuai ideologinya. Dengan demikian berarti identitas media ditentukan dan dipengaruhi oleh ideologi media, "Ideologi sebuah media terlihat nyata di dalam halaman editorialnya" (Fenny, 2009, p.7). Jadi sudah jelas jati diri media terlihat melalui editorialnya. Setelah dilihat dengan metode analisis framing. Akhirnya didapatkan beberapa bingkai yang mencerminkan ideologi masing-masing Surat Kabar (Suara Pembaruan, Media Indonesia, Republika). Di bawah ini akan dibahas mengenai ketiganya.

\section{Suara Pembaruan vs Media Indonesia vs Republika}

Dari tabel di atas dapat dilihat pemetaan konstruksi ketiga media di atas terkait isu konflik Israel-Palestina. SP secara spesifik melihat konflik Israel-Palestina sebagai konflik antara kelompok politik Hamas dan Israel. Sedangkan MI dan Republika memandang kasus ini sebagai agresi Israel ke Jalur Gaza, ini berarti pihak Israel dianggap aktif menyerang dan posisi Jalur Gaza adalah pasif (sebagai daerah sasaran serangan). Membahas konflik ini, SP pesimis bahwa konflik ini akan berakhir, apalagi dalam paragraf delapan, SP menyatakan bahwa konflik ini berakar pada konflik berkepanjangan. Sedangkan MI dan Republika lebih memilih untuk menyoroti penyebab konflik tersebut, dan tentu saja menjabarkan betapa kejam dan salahnya tindakan yang dilakukan oleh Israel terhadap Palestina. Alih-alih berbicara mengenai mustahil tidaknya konflik ini berakhir, MI dan Republika lebih memilih mengecam semua pihak yang tidak segera memberi kemerdekaan bagi Palestina.

Frame yang digunakan oleh SP dalam membingkai resolusi adalah dengan mengangkat sisi positifnya. SP menyoroti kegagalan ketetapan-ketetapan sebelumnya untuk menggiring pembacanya berpikir sisi positif Resolusi 1860 yang berhasil meredam aksi saling serang antara Israel-Hamas. Namun ada fakta yang tidak disebutkan SP yaitu bahwa hanya beberapa jam saja setelah resolusi ini ditetapkan, Israel malah menyerang Jalur Gaza disaat Jalur Gaza dalam keadaan gencatan senjata. Dikatakan dalam editorial Republika (par. 5), Israel malah menyerang membabi buta,

"Israel tidak peduli walau dewan keamanan PBB telah menyetujui resolusi yang menyerukan segera diakhirinya konflik bersenjata. Pada jumat (9/11) kemarin, pemerintah zionis malah kian gencar melancarkan serangan di Jalur Gaza. Tidak tanggung-tanggung 50 serangan udara dilancarkan bertubi-tubi. Tak peuli anak-anak atau kaum perempuan. Tak peduli fasilitas umum maupun fasilitas ibadah. Mereka (Palestina), merasa dibohongi, tatkala melakukan gencatan senjata, Israel malah membabi buta menyerang wilayah Gaza".

Paragraf di atas bertolak belakang dengan apa yang ditulis SP pada editorialnya. SP sama sekali tidak menuliskan adanya serangan besar-besaran yang dilakukan Israel terhadap Jalur Gaza hanya sehari setelah Resolusi 1860 ditetapkan. Mengapa SP berbeda bahkan terkesan bertolak belakang dengan Republika? Dalam hal ini terlihat "dua aspek framing, yang pertama memilih fakta atau realitas, proses ini didasarkan pada asumsi, dan mengandung dua kemungkinan: apa yang dipilih

(included) dan apa yang dibuang (excluded). Kedua, menuliskan fakta, proses ini berhubungan dengan bagaimana fakta yang dipilih itu disajikan kepada khalayak melalui kata, kalimat dan proposisi, juga pemakaian label tertentu" (Eriyanto, 2007, 
p.69-70). SP menutup fakta bahwa Resolusi ini sebenarnya hanya mampu meredam beberapa sehari saja karena keesokan hari setelah Resolusi ini ditetapkan, Israel kembali menyerang secara besar-besaran.

Dari paragraf yang ditulis Republika mengenai Resolusi 1860 DK-PBB dan apa hasilnya, Republika tampak jelas memilih untuk mengupas habis mengenai kegagalan resolusi tersebut dalam mengatur Israel, dan yang paling tampak ingin disajikan Republika adalah mengenai betapa sangat buruknya perilaku bangsa Israel. Jelas dalam hal ini Republika tampak konsisten dengan landasan ideologinya.

Selain dipengaruhi oleh nilai-nilai Islam, Republika juga menyadari bahwa khalayak pembacanya banyak dari kalangan muslim dan lagi di Indonesia, nilai-nilai Islam adalah juga nilai yang dianut hampir seluruh masyarakat Indonesia, Gandhi dalam buku 'Konflik Israel-Palestina menyatakan bahwa Indonesia merupakan negara berpenduduk muslim terbesar di dunia (Gandhi, 2009, p.134). Republika memilih fakta dan menyajikannya sesuai dengan selera pembacanya yang mayoritas muslim.

Kalau sedari tadi membandingkan SP dan Republika kini giliran MI. MI memilih untuk tidak meyoroti kegagalan Resolusi 1860 ini secara khusus, MI menggeneralisasi seluruh upaya diplomasi yang digunakan, apapun sebutan bagi upaya diplomasi itu, "resolusi, perjanjian, persetujuan dan lain sebagainya" disebut sebagai upaya yang sia-sia dan justru mempersulit Palestina. Editorial MI (par. 7) menyoroti inkonsistensi Israel dalam memenuhi hal yang telah disepakatinya. "Upaya diplomasi kerap dimanfaatkan Israel untuk memperkuat diri dan melancarkan tipu daya. Jargon penghapusan permukiman Yahudi di wilayah Jalur Gaza hanyalah salah satu bentuk tipu daya Israel karena mereka memindahkan sebagian permukiman yahudi itu ke wilayah Palestina di Tepi Barat".

Jelas sudah bingkai yang digunakan oleh SP mengenai Resolusi DK-PBB dan jika ditanya mengenai PBB, peneliti yakin SP akan membahas segi positifnya. Namun dalam paragraf-paragrafnya SP tidak membahas mengenai PBB. MI-pun dalam hal ini lebih memilih untuk tidak melihat PBB secara khusus dan menyoroti seluruh kegagalan badan dunia dari berbagai belahan dunia yang telah gagal mendamaikan Israel dan Palestina. Kegagalan ini dipandang MI sebagai kemandulan badan-badan dunia yang disebabkan standar ganda yang mereka gunakan. "...banyak negara, terutama negara-negara Barat yang menerapkan standar ganda", dari kalimat ini peneliti melihat MI mencoba bersikap netral dalam membicarakan badan-badan dunia yang terlibat dalam upaya perdamaian IsraelPalestina. Bahkan ketika MI menyoroti praktek standar ganda yang dilakukan terutama oleh negara Barat, MI menggunakan frasa jamak "negara-negara Barat" dan dalam memberi contoh kasus, MI-pun berusaha untuk tidak hanya menyoroti praktek standar ganda Amerika Serikat seperti yang dilakukan Republika, "Begitu Hamas menguasai pemerintahan Palestina, secepat itu pula Uni Eropa dan Amerika Serikat menghentikan bantuan keuangan yang telah dijanjikan" (Editorial $M I$, para 9).

Dalam paragraf di atas MI benar-benar tampak menyajikan editorialnya sesuai dengan visi-nya: Independen, yaitu menjaga sikap nonpartisan; dan mempunyai keberanian bersikap beda. Lugas, yaitu menggunakan bahasa yang terang dan langsung. Kedua hal ini tercermin dalam pembahasannya mengenai prakek standar ganda yang dilakukan badan-badan dunia. 
Republika satu-satunya di antara ketiga surat kabar yang membahas PBB secara khusus, dan mengidentikkan PBB dengan Amerika Serikat (Amerika Serikat mendominasi fungsi PBB). Republika sama sekali tidak membahas mengenai badanbadan dunia lain, hanya menyoroti PBB dan kegagalannya, "kelumpuhannya". Di awal paragrafnya Republika tampak menyadari bahwa PBB tidak hanya terdiri dari Amerika Serikat "sekutu Israel" (par. 6), namun juga bangsa-bangsa lain yang dalam kalimatnya dikatakan bahwa PBB menyadari kebengisan Israel setelah terjadi peristiwa pemboman di Zaitun, Palestina terjadi. PBB yang dibicarakan di sini adalah PBB secara keseluruhan kecuali Amerika Serikat yang abstain dalam pemungutan suara Resolusi 1860. Republika dalam framenya menekankan bahwa kelumpuhan $P B B$ disebabkan dominasi Amerika Serikat yang tidak semestinya. Pandangan Republika mengenai Amerika Serikat sebagai sekutu Israel juga bukan tanpa alasan, kutipan berikut ini menyatakan adanya identifikasi bahwa Amerika Serikat adalah sekutu Israel, "Tak ada perbedaan antara Menlu AS dari Republik dan Demokrat. Keduanya, mempunyai pandangan yang sama, karena siapapun yang berada di Gedung Putih, pasti akan mengabdi kepada Israel" (Dialog Islam-Kristen : Amerika Serikat adalah Israel, par.1).

Dalam frame Republika, konflik Israel-Palestina terkait dengan isu SARA. Republika tampak memandang masalah ini (konflik Israel-Palestina) mengandung unsur SARA. Republika menyebutkan tindakan Israel yang juga merusak fasilitas ibadah (agama) dan Republika menyebut Israel sebagai "pasukan Zionis". Maxime Rodinson dalam bukunya yang berjudul Israel, Colonial Settler State menyatakan bahwa Zionisme memang merupakan gerakan rasialis yang mencita-citakan negara yang 'murni' ras Yahudi. Sejak semula ideologi ini tidak memberi ruang sama sekali bagi bangsa-bangsa lain untuk bisa hidup bersama secara damai. Dalam cita-citanya kaum Zionis akan menguasai Palestina dan menjadikannya sebagai negara khusus Yahudi (Prof Jacob Katz \& Friends, 1997, p. vii).

Dalam mengkonstruksikan Israel, SP bertolak belakang dengan MI dan Republika. SP mengkonstruksikan Israel sebagai pihak yang diserang terlebih dahulu sehingga Israel membalas serangan yang diarahkan padanya. Sebaliknya,dalam konstruksi MI, serangan Hamas justru merupakan tindakan responsif atas perlakuan Israel di Jalur Gaza. Israel terlebih dulu menutup pintu-pintu perbatasan yang menyulitkan warga Palestina memperoleh kebutuhan sehari-hari mereka. Israel juga dianggap melakukan serangan terhadap Jalur Gaza demi kepentingan politik dalam negerinya sendiri, alasan yang sangat menunjukkan betapa kejamnya Israel yang menjadikan Jalur Gaza sebagai "panggung unjuk gigi". Republika senada dengan MI mengecam tindakan Israel yang menyerang tanpa pandang bulu, dan menyoroti korban-korban yang berjatuhan akibat kekejaman Israel terhadap warga Palestina.

SP memandang Hamas sebagai kelompok yang memicu serangan-serangan Israel, berikut pernyataan SP dalam paragraf keenamnya: "Jadi, konflik HamasIsrael melalui serangan-serangan roket, sejak Hamas menguasai Gaza tahun 2006 dan selalu dibalas Israel, hanya sebuah tahap akhir yang belum tentu berakhir tuntas". SP menggambarkan Hamas sebagai kelompok ekstrim yang tidak mau menyerah dan terus menyerang Israel yang jelas jauh lebih kuat darinya, dan akibat keekstrimannya itu, penduduk Palestina justru menjadi semakin terpuruk. Jika SP berpandangan seperti itu, lain halnya dengan MI yang melihat pendekatan militeris 
Hamas justru sebagai jawaban atas kekecewaan rakyat Palestina terhadap upaya diplomasi yang dilakukan Faksi Fatah. MI-pun menegaskan bahwa pendekatan militeris ini terbukti menjadi jawaban bagi rakyat Palestina karena rakyat Palestina mendukung Hamas dalam Pemilu. Dengan adanya fakta tersebut, MI menilai pendekatan militeris Hamas dirasakan lebih baik oleh rakyat Palestina. Republika juga mengangkat konstruksi yang sama dengan MI mengenai Hamas, bahwa Hamas-lah kelompok yang peduli dan memikirkan kebutuhan rakyat Palestina, maka apapun atau siapapun yang dianggap tidak dapat menjawab kebutuhan rakyat Palestina sama dengan bertolak belakang dengan kepentingan Hamas. Hamas digambarkan bagai pahlawan yang menentang siapa saja termasuk PBB yang tidak dapat menjawab kebutuhan rakyat Palestina.

Pada akhirnya, masing-masing surat kabar ini menyuguhkan solusi dan berusaha memberikan pandangan mengenai bagaimana masalah tersebut harusnya diselesaikan. Sekali lagi SP menyuguhkan sesuatu yang berbeda dari dua surat kabar lainnya. SP memandang pendekatan militeris yang dilakukan Hamas justru memperburuk keadaan, menurut SP hal terbaik yang harusnya dilakukan Palestina adalah menghadapi Israel dengan sikap moderat dan mewujudkan persatuan dan rekonsiliasi nasional Palestina. Jika SP justru mendukung dilakukannya upaya diplomatis dalam menghadapi Israel, MI dan Republika justru sebaliknya. MI dan Republika memandang percuma upaya diplomasi dan melihat pendekatan militeris yang dilakukan Hamas sebagai solusi yang lebih baik. MI lebih jelas lagi menyatakan upaya diplomasi malah kerap dimanfaatkan Israel untuk memperkuat diri dan melancarkan tipu daya maka jelas upaya diplomasi tidak seharusnya dilakukan lagi, dan konflik ini akan berakhir jika Palestiina telah diberi kemerdekaan. Republika juga menganggap percuma upaya diplomasi karena Israel telah mengabaikan Resolusi 1860 DK-PBB.

\section{KESIMPULAN}

Suara Pembaruan, Media Indonesia, dan Republika menuangkan bingkai yang berbeda-beda dalam editorialnya masing-masing terkait kasus Gaza, khususnya mengenai serangan Israel ke Jalur Gaza setelah Resolusi DK-PBB 1960 yang menyatakan gencatan senjata ditetapkan. Dalam editorialnya SP memilih fakta tertentu untuk diangkat dalam beberapa fakta yang lain. Mengenai Resolusi DKPBB 1860, SP tidak menyebutkan adanya serangan Israel terhadap Palestina yang sedang dalam kondisi gencatan senjata. SP juga menutup fakta bahwa serangan ini dilakukan Israel hanya beberapa jam setelah Resolusi DK-PBB ditetapkan. Sebaliknya SP justru menyatakan Resolusi ini telah berhasil meredam konflik yang sedang terjadi di Jalur Gaza ditambah lagi SP menganggap Resolusi ini sebagai sebuah kemajuan. SP memperlihatkan bahwa Resolusi ini lebih berhasil dan ampuh meredam konflik dibandingkan dengan beberapa ketetapan dan Resolusi sebelumnya yang telah gagal karena diabaikan Israel. Dari hal ini peneliti melihat adanya pemilihan dan penulisan fakta yang dilakukan oleh SP. Pemilihan fakta dan penulisan fakta yang dilakukan oleh SP dilakukan berdasarkan ideologi yang telah dipengaruhi beberapa hal tidak hanya faktor internal namun juga eksternal, pemilik modal, pembacanya, dan hal-hal lain yang menunjang eksistensi surat kabar ini. 
Ideologi SP dipengaruhi nilai-nilai Kristen yang sarat dengan 'kasih'. Sampai saat ini di Indonesia, Kristen masih identik dengan negara Barat khususnya Amerika Serikat yang identik dengan PBB. Peneliti melihat meski SP tidak secara langsung menampakkan bingkai SARA dalam editorialnya, namun pengaruh nilai Kristennya tampak ketika SP tidak ingin memperlihatkan kesan negatif dalam tulisannya mengenai PBB. Landasan kasih yang sangat kental dalam kekristenan diperlihatkan melalui paragraf-paragraf awalnya yang menyoroti jumlah korban dari seranganserangan yang Israel lakukan. SP melihat fakta adanya korban dari seranganserangan Israel di Jalur Gaza, namun tak ingin Israel dan PBB terkesan negatif. Maka SP kemudian menjelaskan bahwa serangan yang dilakukan oleh Israel adalah untuk membalas serangan roket Hamas. Dengan demikian SP menyatakan bingkainya bahwa cara militer Hamas yang ekstrim justru menjadi penyebab utama kemalangan rakyat Palestina. Dalam bingkai SP tampak jelas bahwa jalur diplomasi dianggap SP sebagai jalan yang lebih baik, agar tidak ada ada korban berjatuhan akibat tindakan saling serang yang tak henti-hentinya berlangsung. Bingkai agama diperlihatkan SP dengan melihat konflik ini sebagai akibat dari konflik berkepanjangan dan menegaskan bahwa ada tiga pihak yang mengharapkan pulihnya kondisi keamanan di jalur Gaza yaitu dunia, dunia Arab, dan rakyat Palestina sebagai korban. Dunia tentu mewakili begitu banyaknya orang yang mengecam tindakan Israel, dunia Arab secara nilai religi mewakili pihak Islam. Masyarakat internasional menganggap Arab dan Palestina identik dengan Islam, hal ini terlihat jelas dari beberapa demonstrasi yang dilakukan pihak Islam di berbagai belahan dunia. Dunia Arab dan rakyat Palestina sebagai korban yang sudah tentu menginginkan adanya kondisi keamanan yang baik di jalur Gaza.

Media Indonesia dengan ideologi yang kental terpengaruh nilai-nilai kebangsaan, (Buku panduan karyawan MI, 2000, p.14) melihat masalah ini dengan cara pandang yang lebih luas. Tidak spesifik meyoroti PBB tidak spesifik menyoroti satu kasus serangan Israel setelah ditetapkannya Resolusi DK-PBB 1860, namun MI melihat kegagalan badan-badan dunia secara keseluruha dan konflik di Timur Tengah khususnya antara Israel-Palestina sejak awal mula yang hingga saat ini belum terselesaikan. MI tidak menyebutkan bahwa konflik ini terkait dengan SARA atau khususnya agama. MI melihat hal ini sebagai masalah politik yang tidak kunjung terselesaikan akibat standar ganda yang diterapkan oleh badan-badan dunia. SP melihat Palestina sebagai korban permainan politik Israel, bahkan digunakan sebagai "panggung unjuk gigi" oleh partai-partai politik di Israel agar mendapat simpati rakyat Israel saat Pemilu. Dalam bingkainya memang terlihat kecenderungan pemilihan fakta MI yang sedikit memojokkan negara-negara Barat dan ada kalanya MI menyebutkan negara Barat tanpa kata jamak yang menunjukkan adanya satu begara Barat yang kental menerapkan standar ganda. MI melihat kegagalan proses perdamaian menjadi tanggung jawab setiap pihak yang seharusnya memiliki kuasa untuk mendamaikan. Ketika membahas Israel, bingkai yang ditampakkan MI adalah bahwa Israel melakukan agresi di Jalur Gaza demi kepentingan politiknya. MI melihat Israel penuh tipu daya dalam tindakannya, maka dari itu upaya diplomasi yang sarat dengan kesepakatan-kesepakatan politik justru tidak menguntungkan bagi Palestina. Menurut MI, pemberian kemerdekaan terhadap Palestina adalah langkah yang utama. Palestina tidak boleh lagi menjadi sasaran permainan politik dalam negeri Israel. 
Di antara ketiga surat kabar ini bingkai Republika yang nampak jelas mengangkat bingkai SARA, Republika menyebut pasukan Israel dengan sebutan zionis yang merupakan sebutan bagi pengikut paham atau gerakan Zionisme. Maxime Rodinson menyebutkan dalam bukunya bahwa Zionisme merupakan gerakan rasialis yang mencita-citakan negara yang 'murni' ras Yahudi. Republika juga menyebutkan perusakan-perusakan Israel yang salah satunya adalah perusakan tempat umum dan tempat ibadah. Republika tampak konsisten dengan landasan ideologi yang kental dengan nilai-nilai Islam yang menjadi dasar setiap tulisannya. Terhadap Israel, Republika memperlihatkan sisi kekejamannya terhadap bangsa Palestina yang lemah, hal ini terlihat ketika dalam paragraf-paragraf awal tajuknya. Alih-alih membahas kegagalan Resolusi DK-PBB 1860, Republika memilih untuk terlebih dahulu menuliskan peristiwa yang dianggapnya paling kelam dalam rangkaian agresi Israel yang dimulai sejak 27 desember 2008 yaitu peristiwa pemboman yang dilakukan pasukan Israel terhadap pengungsi Palestina di Zaitun. Selain dipengaruhi oleh nilai-nilai Islam, segmentasi pembaca Republika yang mayoritas adalah kaum muslim kekonsistenan Republika didukung dengan adanya fakta bahwa nilai Islam adalah juga nilai yang dianut hampir seluruh masyarakat Indonesia (Gandhi dalam buku 'Konflik Israel-Palestina menyatakan bahwa Indonesia merupakan negara berpenduduk muslim terbesar di dunia). Republika memilih fakta dan menyajikannya sesuai dengan selera pembacanya yang mayoritas muslim (Gandhi, 2009, p.134).

Republika melihat PBB sebagai kumpulan negara yang lumpuh akibat dominasi Amerika Serikat yang dianggap Republika sebagai sekutu Israel, dari kutipan berikut ini membuktikan bahwa Republika bukannya tanpa alasan menyebut Amerika Serikat sebagai sekutu Israel "Tak ada perbedaan antara Menlu AS dari Republik dan Demokrat. Keduanya, mempunyai pandangan yang sama, karena siapapun yang berada di Gedung Putih, pasti akan mengabdi kepada Israel" (http://kristolog.blogspot.com/2009/03/amerika-serikat-adalah-israel.html). PBB (minus Amerika Serikat dan Israel) dikatakan hanya dapat mengutuk tindakan biadab Israel tanpa dapat berbuat apa-apa. Resolusi yang dihasilkan DK-PBB pun mengalami jalan buntu dan tidak berguna. PBB tidak dapat melindungi rakyat Palestina dari kekejaman Israel dan Konflik ini dikatakan sebagai agresi Israel terhadap Jalur Gaza.

Dari hasil penelitian ini terbukti bahwa keragaman ideologi media berdampak pada editorial yang dihasilkan. Maka masyarakat pembaca tidak seharusnya begitu saja membaca dan menerima setiap informasi yang disajikan media massa. Sebisa mungkin menjadi lebih kritis dalam melihat setiap tulisan baik editorial maupun pemberitaan yang dimuat dalam media cetak dan memahami teks media sebagai teks yang dikonstruksikan terlebih dahulu sebelum diterjemahkan dalam teks.

\section{SARAN PENELITI}

Penelitian ini melengkapi penelitian-penelitian sebelumnya dengan metode analisis framing. Dengan demikian gambaran pembaca mengenai media-media cetak yang ada di Indonesia semakin diperjelas. Penelitian ini bersifat kualitatif dan tidak dapat digeneralisasikan, maka peneliti mendorong akademisi komunikasi yang lain untuk dapat melanjutkan penelitian mengenai konflik di Timur Tengah yang sampai 
saat inipun belum berakhir, khususnya antara Israel-Palestina. Konflik terpanjang ini masih dapat dijadikan bahan penelitian yang menarik dan aktual. Dalam proses pengerjaan penelitian ini, peneliti juga mendapati bahwa penelitian kualitatif tidak harus dilakukan dengan membandingkan beberapa media, karena pendekatan kualitatif lebih menekankan kepada kedalaman penelitian. Bagaimanapun setiap penelitian memiliki keterbatasan, baik dalam perangkat penelitian yang digunakan maupun peneliti sendiri, maka topik kasus Gaza ini dapat diteliti dengan metode lain yang dapat melengkapi gambaran sikap media, baik pemberitaannya maupun tajuknya. Media cetak-pun dapat mengalami pergeseran nilai-nilai seiring dengan perubahan kepemilikan maupun perubahan insan-insan di dalam institusinya, tidak salah jika nantinya topik penelitian ini diteliti kembali dengan membandingkan media yang sama namun teks yang berbeda.

Menyadari adanya dampak teks media yang cukup signifikan terhadap bingkai dan konstruksi berpikir masyarakat pembaca, maka peneliti menyarankan kepada setiap media di Indonesia dari latar belakang apapun hendaknya meresponi dan menulis dengan lebih bijak. Hendaknya media tidak hanya memikirkan bagaimana institusinya dapat bertahan dan pandangannya diterima oleh pembacanya, namun juga memikirkan apa yang terbaik bagi pembacanya. Tidak dapat dipungkiri memang, terkadang media tidak sadar beberapa tulisannya secara tidak sengaja memuat bingkai tertentu yang oleh penulisnya sendiri dianggap sebagai fakta. Padahal fakta yang dituliskannya bisa jadi bukan fakta yang sebenarnya melainkan fakta yang telah dikonstruksi terlebih dahulu, mengingat bahwa setiap orang memiliki persepsi yang berbeda-beda mengenai satu hal yang sama. Oleh karena itu dengan adanya penelitian ini diharapkan para insan pers menilik ulang apa yang akan disajikannya dalam sebuah teks sebelum teks tersebut benar-benar disajikan kepada pembacanya.

Setelah mengetahui bahwa adanya bingkai tertentu yang disajikan oleh media sebagai hasil dari konstruksi media dari berbagai latar belakang, maka diharapkan masyarakat pembaca bisa lebih kritis dalam membca teks yang disajikan oleh media. Masyarakat sebisa mungkin menyadari bahwa ada oknum-oknum dengan kepentingan tertentu yang dapat mempengaruhi bingkai media sehingga menjadi teks yang tidak murni sesuai dengan realita yang ada. Sehingga masyarakat tidak begitu saja percaya dan menganggap setiap informasi dan opini yang disajikan media sebagai fakta.

\section{DAFTAR PUSTAKA}

Antara Zionisme dan Yahudi. Retreive 12 Oktober 2009, from http://www. harunyahya. com/indo/artikel/046.htm.

Berger, P. L., 2007. Sociology as a form of consciousness invitation to sociology, from http://www.angelfire.com/or/sociologyshop/berger2.html.

Devereux, E., 2003. Understanding the media. London: SAGE.

Edward, H. S., Shomsky, N., 1988. Manufacturing concent the political economy of the mass media. London: Vintage. 
Eriyanto, 2007. Analisis framing: Konstruksi, ideologi, dan politik media. Yogyakarta: PT LKIS Pelangi Aksara.

Fenny, 2009. Membongkar ideologi media cetak pada tajuk rencana penyerangan massa AKKBB oleh FPI di lima koran nasional Indonesia. (TA No: 20010447/ KM/2009). Universitas Kristen Petra Surabaya.

Flick, U., 1998. An introduction to qualitative research. London: SAGE.

Gandhi, T. W., 2009. Akar konflik Israel-Palestina: Tinjauan demografi, sejarah, geopolitik, dan agama. Yogyakarta: Ramadhan Press.

Goodman, A., Goodman, D., 2006. Perang demi uang, from http://www.parasindonesia. com/book.php?gid=s.

Hamad, I., 2004. Konstruksi realitas politik dalam media massa. Jakarta: Granit.

Kamus besar bahasa Indonesia, 2000. Jakarta: Balai Pustaka.

Kadri, 2006. Ideologi dan media massa, Jurnal Ilmiah Communigue, Vol 2, No.2.

Lichtenberg, J., 2002. Foundations and limits of freedom of the press. (Denis Mcqual). London: SAGE.

Lippman, W., 1992. Stereotypes, public opinion, ang the press. (Elliot D. Cohen, Ed.). New York: Oxford University Press.

Littlejohn, S. W., Fos, A. F., 2005. Theories of human communication. Canada: Wadsworth.

Masduki, 2001. Jurnalistik radio. Yogyakarta: PT LKIS Pelangi Aksara.

Membedakan Zionisme dari Yahudi, Retreive 20 Oktober 2009, from http://www. harunyahya.com/indo/artikel/049.htm

Moleong, L. J., 2005. Metodologi penelitian kualitatif. Bandung: PT Remaja Rosdakarya.

Mulyana, D., 2005. Ilmu komunikasi, suatu pengantar. Bandung: Remaja Rosdakarya.

Nimmo, D., 1993. Komunikasi politik: Komunikator, pesan, dan media. (Tjun Surjaman). Bandung: Remaja Rosdakarya.

Panjaitan, G., 2008. Konstruksi pemberitaan tentang perang antar Israel dan Hezbullah-Lebanon. Unpublished Undergraduate Thesis, Airlangga University, Surabaya.

Panuji, R., 2005. Dasarnya dasar jurnalistik. Malang: Banyumedia

Santanak, S., September 2002. Politik bisnis media. Library unisba.co.id, Retrieved September 3, 2002, from http://library.unisba.co.id/artikel/artikel-sept-030902doc.

Scheufele, D. A., Tewksbury, D., 2007. Framing, agenda setting, and primity: the evolution of three media effect models. International Communication. Journal Communication. 
Shoemaker, P. J., Reese, S. D., 1996. Mediating the message-Theories of influences on mass media content. USA: Logman Publisher.

Siburian, S. P., 2007. Pers dan pemilihan presiden di Indonesia, analisis framing Isu demokratisasi dalam tajuk rencana Kompas, Suara Pembaruan, Republika, dan Jawa Pos pada pemilihan presiden 2004. (TA No. KKB KK-2 TSK 01/07 Sib P). Unpublished Undergraduate Thesis, University Airlangga, Surabaya.

Stovall, J. G., 2005. Jounalism who, what, when, where, why, and how, from Pearson Education, Inc.

Subiakto, H., 1997. Dominasi negara dan wacana pemberitaan pers dalam masyarakat dan negara (Bambang Susilo, Ed.). Surabaya: Airlangga University Press.

Amerika Serikat adalah Israel http://kristolog.blogspot.com/2009/03/amerika-serikatadalah-israel.html.

www.infoanda.com/linksfollow.php?lhVQ8PVVBVUAdU.

Profil Republika, Retreived 12 Oktober 2009. www.republika.co.id/halaman/23. 